Sylvia Wynter 



\section{Sylvia Wynter}

Katherine McKittrick, ed.

Duke University Press Durham and London 2015 
(C) 2015 Duke University Press

All rights reserved

Printed in the United States of America on acid-free paper $\infty$ Designed by Heather Hensley

Typeset in Arno Pro by Graphic Composition, Inc.

Library of Congress Cataloging-in-Publication Data

Sylvia Wynter : on being human as praxis / Katherine McKittrick, ed. pages $\mathrm{cm}$

Includes bibliographical references and index.

ISBN 978-o-8223-5820-6 (hardcover : alk. Paper)

ISBN 978-o-8223-5834-3 (pbk. : alk. paper)

1. Wynter, Sylvia. 2. Social sciences-Philosophy. 3. Civilization, Modern-Philosophy. 4. Race-Philosophy. 5. Human ecology_Philosophy. I. McKittrick, Katherine.

HM585.S95 2015

$300.1-\mathrm{dc} 23$

2014024286

ISBN 978-o-8223-7585-2 (e-book)

Cover image: Sylvia Wynter, circa 1970s. Manuscripts, Archives and Rare Books Division, Schomburg Center for Research in Black Culture, The New York Public Library, Astor, Lenox and Tilden Foundations.

Duke University Press gratefully acknowledges the Canadian Social Sciences and Humanities Research Council (ssHrC/Insight Grant) which provided funds toward the publication of this book. 
For Ellison 
